\title{
Arable weeds of the Scottish Borders
}

\author{
Michael E. Braithwaite ${ }^{1 *}$, Luke W. Gaskell ${ }^{2}$ \\ ${ }^{1}$ Hawick, Scotland; ${ }^{2}$ Melrose, Scotland
}

*Corresponding author: Michael E. Braithwaite: mebraithwaite@btinternet.com

This pdf constitutes the Version of Record published on $26^{\text {th }}$ July 2021

\begin{abstract}
Many years of fieldwork have led the authors to hypothesise that there is a single relatively species-rich arable weed community present across the Scottish Borders that is best expressed in broad-leaved root crops and in set-aside on imperfectlydrained soils, while the species-poor communities typically found in cereal crops are a degraded form of this. 102 samples have been studied to test this hypothesis and to search for a community typical of slightly calcareous well-drained soils. The community typical of imperfectly-drained soils has been defined and is considered to be a species-rich variant of the NVC OV13 Stellaria media-Capsella bursa-pectoris open habitat community. Species typical of well-drained soils have been shown to be scarce and not to form a distinct community, though they may well have done so in the past.
\end{abstract}

Key words: vegetation communities, long-lived seedbanks, coincidence maps

\section{Introduction}

The Scottish Borders closely corresponds to the catchment of the River Tweed with the land suitable for cultivation concentrated in the valleys and in a broad sweep of low-altitude land in the east known as The Merse. Ice-age scouring of the land left a notable series of ridges with wetland between the ridges. Most of the wetland was drained in the decades around 1800 , leaving fertile soil enriched by fen peat. The underlying geology is of heavily-folded Silurian greywackes in the hills with a band of Old Red Sandstone in the Central Borders and a tract of calciferous sandstone of the Carboniferous age to the east. True limestone is rare. There is some alluvium. The soils suitable for cultivation are mainly neutral or slightly acid, but there is much small-scale variation.

The early cultivation was on the drier land mostly along ridges. After the drainage of the Agricultural Revolution much additional land was brought into cultivation. Over the years field drainage, liming and fertilising have altered the cultivated land until it is all, within limits, of comparable quality.

One of the authors, Braithwaite (MEB), started systematic botanical recording in 1979, mainly in Berwickshire, while the other, Gaskell (LWG), began in 1999, mainly in the Central Borders. Both MEB and LWG developed a special interest in arable weeds. In addition to records of arable weeds made during general recording both authors made dedicated surveys of arable weeds. Many of MEB's dedicated surveys were in 1986 while LWG's surveys were mainly between 1999 and 2009. 


\section{Methods}

A trial sample was taken of 24 lists made by LWG of the arable weeds in fields where Galeopsis speciosa was found. Analysis confirmed that the presence of this species is a strong indicator of a species-rich community with which MEB was familiar. However, examination of a distribution map at $1 \mathrm{~km}$ scale showed that $G$. speciosa has a curiously localised distribution along the borders of former wetlands. This supported the association with fen peat described by Crawley (2020). MEB's experience suggested that the species-rich arable weed community had a wider distribution than this, so a broader-based sample was sought.

102 samples consisting of a list of the arable weeds in a single field were gathered from the BSBI MapMate dataset for Berwickshire, 52 recorded by MEB and 50 by LWG. Berwickshire was chosen as MEB has had intimate experience of these records as vice-county recorder, enabling him to be aware of bias. The selection process aimed for an even spread across Berwickshire, but in the event a degree of bias had to be accepted. No date-class distinctions were made in selecting samples, as the hypothesis being tested assumes that there is an underlying long-lived seedbank of arable weeds in each field that is maintained, to a greater or less extent, by the arable weeds that flower when the field bears a suitable crop.

MEB had not always made a full species list for the fields surveyed, choosing to omit some of the ubiquitous species and also the perennial species such as grasses and thistles that inevitably seed in from the field headlands. The lists were accordingly culled to focus on the annual species that are specialists of the arable habitat. This left 88 species for analysis.

It was hoped that at least two arable weed communities would be revealed, so indicator species were selected from the data from the $G$. speciosa sample in the hope that they would point to a community of imperfectly-drained soils (a 'wet' community) and a similar selection was sought for species of slightly calcareous well-drained soils (a 'dry' community). Species for a 'dry' community were chosen on the basis of their national distribution in the New Atlas of the British Flora (Preston et al., 2002). The selection is necessarily biased towards species near the northern limit of their range where they tend to be coastal.

The 102 samples were analysed and subsets were chosen to test whether communities emerged. The first attempt was promising but several of the indicator species were found to have unexpectedly similar frequencies in the 'dry' and 'wet' subsets. The analysis was accordingly re-run with revised selections. These proved adequate for the intended purpose.

Of the 102 samples, 49 were allocated to the 'wet' samples, 23 to the 'dry' samples with 30 left as intermediate. Of the 49 'wet' samples, 24 included $G$. speciosa. The great majority of the samples are taken from broad-leaved root crops, fields of young grass or in set-aside, though the 'dry' samples include allotment gardens and the soil heaps on a building site over former arable land. Nomenclature follows Stace (2019).

\section{Results}

Arable weed community on imperfectly-drained soils

The 49 'wet' samples were used to prepare a frequency table (Table 1). 
Table 1. Arable weed community on imperfectly drained soils

\section{Indicator species}

Chenopodium album

Fallopia convolvulus

Persicaria maculosa

Galeopsis tetrahit agg.

Spergula arvensis

Galeopsis speciosa

Raphanus raphanistrum subsp. raphanistrum

Thlaspi arvense

\section{Other frequent species}

Atriplex patula

Capsella bursa-pastoris

Fumaria muralis subsp. boraei

Matricaria discoidea

Polygonum aviculare agg.

Sonchus asper

Stellaria media

Fumaria officinalis

Lamium purpureum

Myosotis arvensis

Poa annua

Senecio vulgaris

Sinapis arvensis

Tripleurospermum inodorum

Viola arvensis

Aphanes arvensis agg.

Avena fatua

Euphorbia helioscopia

Veronica persica
Frequency (20\% bands)

$\mathrm{V}(81-100 \%)$

$\mathrm{V}$

$\mathrm{V}$

IIII $(61-80 \%)$

IIII

III (41-60\%)

III

III

V

$\mathrm{V}$

$\mathrm{V}$

V

$\mathrm{V}$

$\mathrm{V}$

$\mathrm{V}$

IIII

IIII

IIII

IIII

IIII

IIII

IIII

IIII

III

III

III

III

\section{Species with frequency II (21-40\%)}

Bromus hordeaceus, Epilobium ciliatum, Epilobium montanum, Geranium dissectum, Geranium molle, Lamium confertum, Lapsana communis, Lycopsis arvensis, Papaver dubium, Plantago major, Taraxacum agg., Veronica arvensis.

\section{Species with frequency I (1-20\%)}

Amsinckia micrantha, Anisantha sterilis, Arabidopsis thaliana, Atriplex prostrata, Barbarea intermedia, Barbarea vulgaris, Bromus racemosus, Bromus secalinus, Cardamine hirsuta, Centaurea cyanus, Cerastium glomeratum, Epilobium obscurum, Epilobium parviflorum, Erodium cicutarium, Erysimum cheiranthoides, Euphorbia peplus, Fumaria bastardii, Fumaria densiflora, Fumaria purpurea, Geranium pusillum, Glebionis segetum, Gnaphalium uliginosum, Isolepis setacea, Lamium amplexicaule, Lamium hybridum, Lysimachia arvensis, Matricaria chamomilla, Mentha arvensis, Myosotis discolor, Papaver lecoqii, Papaver rhoeas, Persicaria lapathifolia, Senecio 
viscosus, Silene latifolia, Sinapis alba, Sisymbrium officinale, Urtica urens, Veronica agrestis, Viola tricolor subsp. tricolor, Vulpia myuros.

The eight species selected as indicators all have high frequencies, as would be expected. They are noticeable in the field as they may be plentiful. Other noticeable species are the fumitories. Fumaria muralis subsp. boraei is constant, while Fumaria officinalis is almost so. Three further Fumaria species are occasional. Euphorbia helioscopia is sometimes plentiful. Three Lamium species in addition to $L$. purpureum are represented. The northern $L$. confertum is more frequent than $L$. amplexicaule and $L$. hybridum which are southern species.

The community appears to be a variant of the National Vegetation Classification OV13 Stellaria media-Capsella bursa-pectoris open habitat community (Rodwell, 2000), nearest to the Fumaria-rich sub-community.

The 24 samples with Galeopsis speciosa were also analysed on their own. The only companion species to show an increased frequency was Galeopsis tetrahit agg. ( $G$. bifida and $G$. tetrahit). It seems that Galeopsis speciosa does not define a separate community in the Scottish Borders.

In 1986 MEB observed the deep drainage of a field at Huntlywood NT6342 which lies on a slope down to Gordon Moss, a large wetland complex. In 2003 the field was in set-aside and LWG recorded the flora which included Fumaria bastardii, F. densiflora, F. muralis subsp. boraei, F. officinalis, Galeopsis speciosa, G. tetrahit agg., Lamium amplexicaule, L. hybridum, Lycopsis arvensis, Papaver dubium, Raphanus raphanistrum subsp. raphanistrum and Thlaspi arvense. This assemblage includes species typical of both 'dry' and 'wet' soils. That so rich a flora has survived is almost certainly due to the disturbance in 1986 of a long-lived seedbank from a time when there was light soil at the head of the field and fen peat mixed with the soil at the foot of the field.

It is an insult to the farmers concerned to seem to suggest that the more species-rich arable weed communities occur on imperfectly-drained soils. On the contrary, almost all the relevant fields have been systematically drained over the last fifty years. It seems that the relatively specialist species came to the fields when they were imperfectly drained and those that have survived are the ones that can tolerate well-drained soils as long as they are not too sandy. Equally they are species that can tolerate high nutrient levels. Species that have been progressively lost to better drainage can be surmised to include Epilobium parviflorum, Gnaphalium uliginosum, Mentha arvensis, Odontites verna and Persicaria lapathifolia.

\section{Arable weed communities on well-drained soils}

When the 23 'dry' samples were analysed none of the species selected as indicators had a high frequency. With their frequencies they were: Lamium amplexicaule (II), Lamium hybridum (III), Lysimachia arvensis (I), Papaver rhoeas (II), Sisymbrium officinale (II), Urtica urens (II) and Sonchus oleraceus (II). The most frequent species in the samples were all very widespread ephemeral species. This suggests that any distinctive 'dry' community is no longer present in the Scottish Borders, though there may well have been such a community in the past along the coastal strip and along the lower part of the River Tweed. More recently the ubiquitous application of inorganic fertilisers, taken together with modern high-yielding seed varieties, has led to dense crops that deprive the weeds of space and light. 
There is a small group of fields near Birgham NT7939, NT8039 in which Papaver rhoeas, not the usual $P$. dubium, is sometimes abundant, particularly the field nearest to the River Tweed which is unique for Berwickshire in lying just above an outcrop of the Carham limestone by the river. Here the light calcareous soil may have reduced the need for fertiliser and allowed the well-recognised long-lived seedbank of $P$. rhoeas to persist in quantity. Nearby, at NT794393, LWG recorded the locally scarce Urtica urens in quantity in potato drills in 2012, again likely to be evidence of a seedbank. This field is the nearest remaining example of an arable weed community corresponding to that of Rodwell's OV14 Urtica urens-Lamium amplexicaule community, but it is only a fragment.

When the 30 samples intermediate between the 'dry' and 'wet' samples were analysed, it was found, as expected, that they lacked distinguishing features. They were species-poor variants of the community on imperfectly-drained soils.

\section{Mapping the results}

While the sampling and analysis was restricted to Berwickshire, it was felt that the results were applicable to the Scottish Borders as a whole (but not any further afield). Coincidence maps were prepared for the eight indicator species on imperfectly-drained soils (Table 1) using tetrad-scale data from the BSBI Distribution Database (https://database.bsbi.org/) with no date-class restrictions. The underlying data in all four vice-counties is taken from a series of sample surveys over different periods. There have not been any complete tetrad surveys. These are presented in Fig.1 (with Calluna mapped to give an indication of hill land not under cultivation):

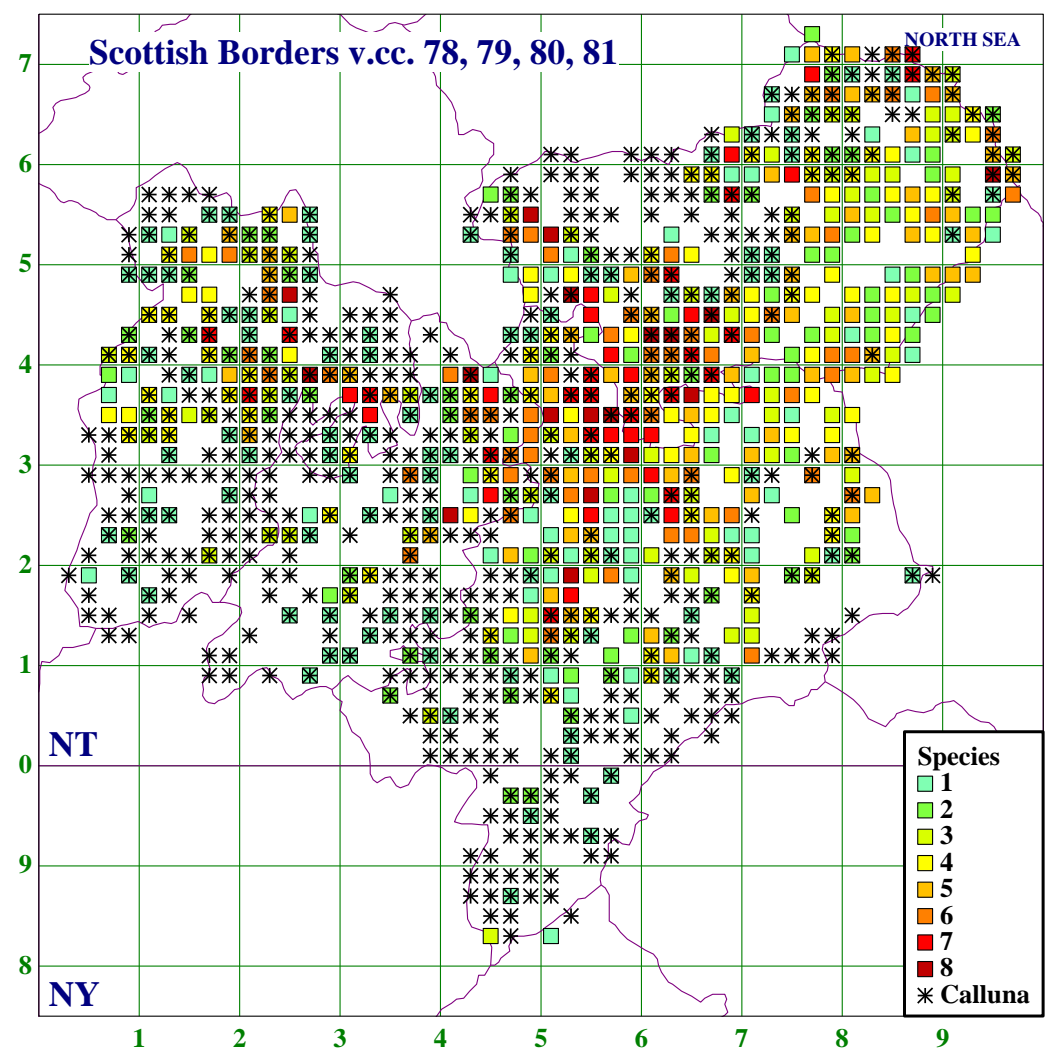

Figure 1. Coincidence map for eight arable species indicating imperfect drainage (the 'indicator species' in Table 1) 
The tetrads with many of the species indicating imperfectly-drained soils are concentrated in the undulating countryside of the Central Borders where many of the farms remain mixed stock farms with sheep and some arable. Roots are commonly grown in rotation for winter feeding and that element of the farming system is what is thought to have preserved the diverse arable weed flora. Recently set-aside and game strips have served the same purpose.

In contrast, the species indicating well-drained slightly calcareous soils (Fig. 2) are scattered thinly across the intensive cereal-growing farms of The Merse and are most prominent along the clifftop fields of the coastal fringe and alluvium along the River Tweed. Nevertheless these species do occur across the whole of the area under cultivation in the Scottish Borders, strongly suggesting that they were more plentiful in the past and were features of an arable weed community that has now been lost. Although there are now unfertilised game strips and set-aside in many of the farms in the cereal belt, the weed floras of such habitat is disappointing, consisting almost entirely of the most widespread ephemeral species.

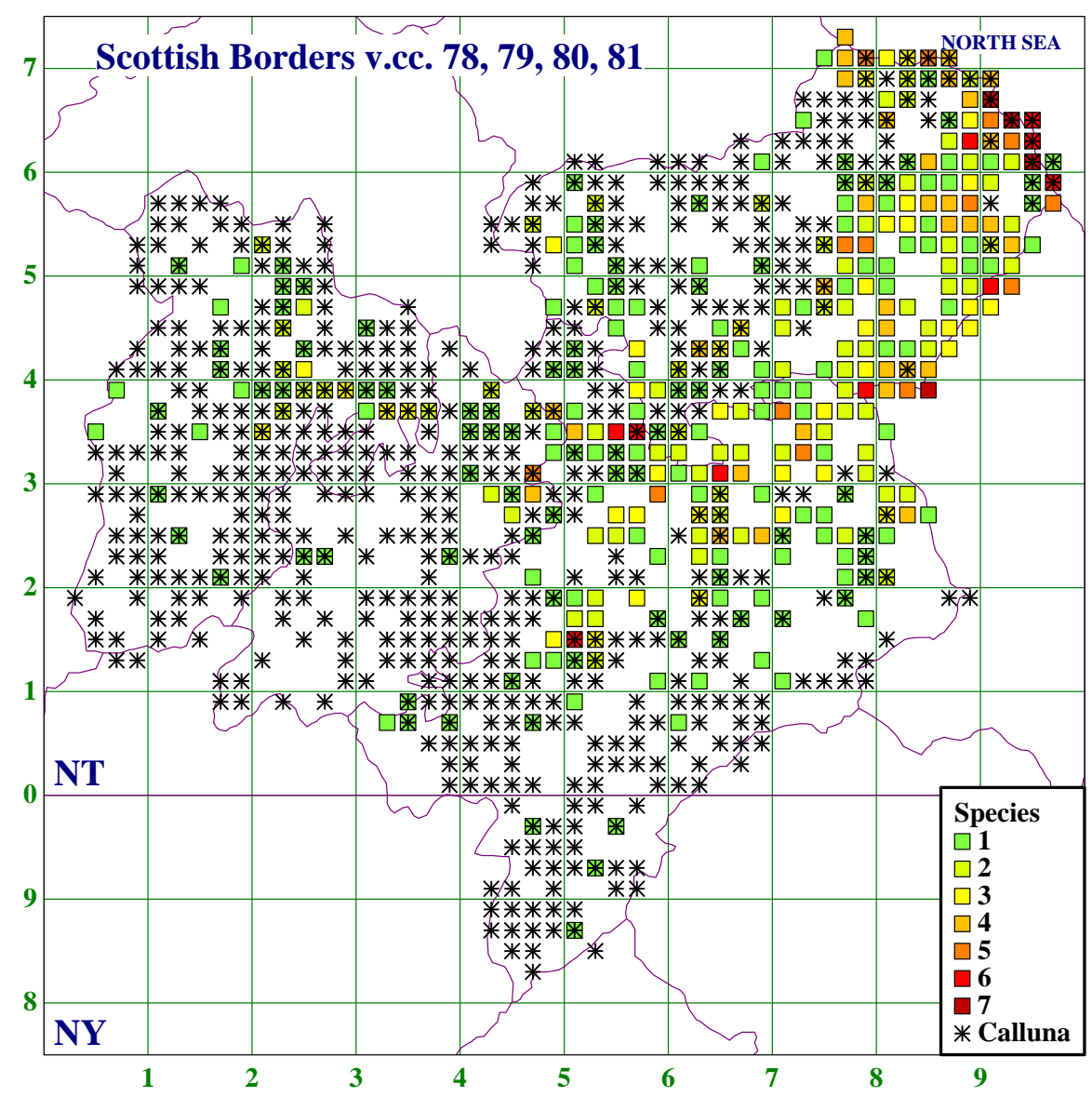

Figure 2. Coincidence map for seven arable species indicating free drainage (the 'indicator species' in the text above)

As the selected indicator species are near the northern limit of their range, they may always have been relatively scarce and thus particularly open to losses when their habitat changed to their disadvantage. 


\section{Distribution of Galeopsis speciosa}

Galeopsis speciosa has a remarkably clustered distribution in the Scottish Borders, best illustrated by the Berwickshire distribution at $1 \mathrm{~km}$ scale (Fig. 3). The largest cluster adjoins the formerly extensive wetland at Gordon Moss NT64 while a further cluster lies on the floodplain of the Leader Water NT45, NT55 where there are thought to have been stands of Carex acutiformis (now lost) forming fen peat. It seems that the association with fen peat noted by Crawley (2020) is a major driver in the distribution of Galeopsis speciosa in the Scottish Borders. Curiously, the species is by no means restricted to the wetter parts of the fields in which it occurs, suggesting that adequate nutrients are as much a requirement as soil moisture and that the reasons for the species to be present in a field relate to historic management rather than current management.

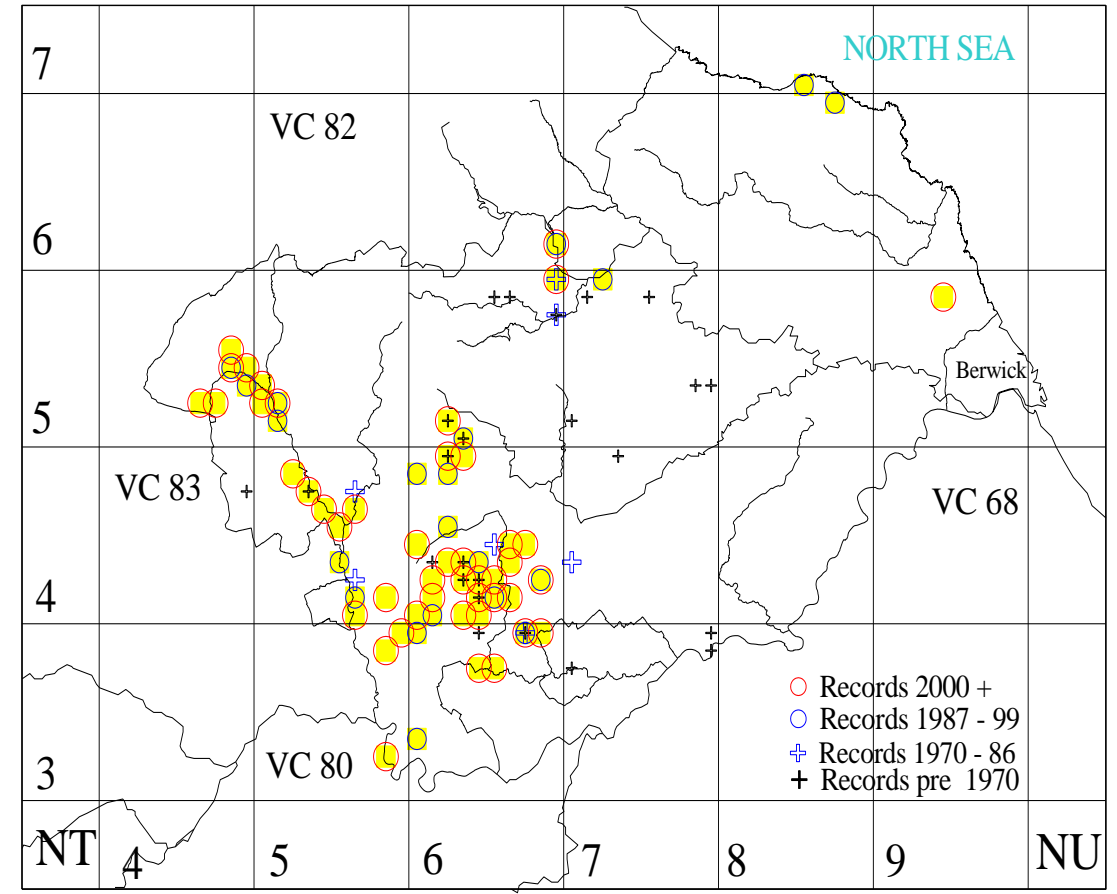

Figure 3. Berwickshire distribution map for Galeopsis speciosa

\section{Other decreasing species}

The following species are now rare as arable weeds in the Scottish Borders (introductions aside) and no longer form part of distinctive communities: Aethusa cynapium, Anthriscus caucalis, Centaurea cyanus, Glebionis segetum and Stachys arvensis. Late-flowering species, such as Stachys arvensis, rely on the stubbles left after harvest to give them time to set seed. The development of winter cereals has led to the earlier ploughing of stubbles to prepare for their sowing and has deprived the specialist weeds of habitat.

\section{Increasing species}

Although many of the more distinctive arable weeds are decreasing, there are several species that are increasing. The species of most concern to farmers are grasses. Avena fatua, an archaeophyte, has had a resurgence, Anisantha sterilis is also increasing in The Merse, perhaps as a response to climate change, and three 
recent colonists Agrostis gigantea, Alopecurus myosuroides and Anisantha diandra

have become established. These have yet to become a widespread problem.

Meanwhile Epilobium ciliatum, which was restricted to infertile soils when it was first recorded in the region in the 1970's, has adapted to fertile soils and is fast becoming a ubiquitous component of the ephemeral flora. Two other broad-leaved species have colonised fairly recently: Amsinckia micrantha and Matricaria chamomilla. Curiously these both prefer sandy soils, a scarce habitat in the Scottish Borders. They have colonised across the full width of the region, but remain local. The Amsinckia has been most successful in sandy fields near Cockburnspath NT77, on alluvium by the River Tweed at Fishwick Mains NT94 and along its tributary, the River Teviot, NT62, NT72, while the Matricaria has been spread by vehicle tyres from large-scale sowings on the embankments of major road realignments. It forms patches near field entrances. Although it is a southern species that may be benefiting from climate change, its prospects in the Scottish Borders are uncertain.

\section{Discussion}

The findings of this review of arable weeds in the Scottish Borders are in line with those of Rodwell, which suggest that the arable weed communities across much of Britain are being reduced to a species-poor community of ephemeral species OV13 (often accompanied by coarse grasses and thistles). However, Rodwell recognises species-rich variants of this community and it is one of these that survives quite widely in the Scottish Borders. The most characteristic species are Fumaria muralis subsp. boraei and $F$. officinalis while $F$. bastardii, F. densiflora and $F$. purpurea are occasional. Galeopsis speciosa is notably well represented as are three Lamium species in addition to L. purpureum: L. amplexicaule, L. confertum and L. hybridum. Also prominent are Euphorbia helioscopia, Raphanus raphanistrum subsp. raphanistrum, Spergula arvensis and Thlaspi arvense. This species-rich community is best expressed in root crops, set-aside and young grass and seems to be indicative of soils that were imperfectly drained in the past. Even with the advantage of the long-lived seedbanks of the characteristic species, the community's future is dependent on mixed farming with sheep and some arable on the margins of the land under cultivation.

Species characteristic of well-drained soils are faring poorly and no longer form a distinctive community, as they are dependent on land that is now intensively managed for cereals where the crop has become too dense to allow them space and light, even without allowing for the use of herbicides. Species affected include Lysimachia arvensis, Papaver rhoeas, Sisymbrium officinale and Urtica urens. However Papaver rhoeas is now often included in seed mixtures sown for wild-bird feed.

The coincidence maps for the Scottish Borders of what were found to be the species most indicative of formerly imperfectly-drained soils and well-drained soils were found to be instructive. They are helpful as a means of visualising the likely distribution of arable weed communities in the past before the advent of modern farming methods.

\section{Acknowledgements}

The coincidence maps were prepared using DMAP (c) Dr Alan Morton. 


\section{References}

BSBI Distribution Database https://database.bsbi.org/ (accessed January 2021).

Crawley, M.J. 2020. Galeopsis speciosa (Lamiaceae): an Open Vegetation seed bank at Worsley in Salford, revealed during construction of the new Royal Horticultural Society Garden at Bridgewater, British \& Irish Botany 2(4): 377406. https://doi.org/10.33928/bib.2020.02.377

Preston, C.D., Pearman, D.A., \& Dines, T.D., eds., 2002, New Atlas of the British and Irish Flora. Oxford: Oxford University Press.

Rodwell, J.S. 2000. British Plant Communities. Vol 5. Maritime communities and vegetation of open habitats. Cambridge: Cambridge University Press.

Stace, C.A. 2019, New Flora of the British Isles, $4^{\text {th }}$ ed. Middlewood Green, Suffolk: C \& M Floristics.

Copyright retained by author(s). Published by BSBI under the terms of the Creative Commons Attribution 4.0 International Public License.

ISSN: $2632-4970$

https://doi.org/10.33928/bib.2021.03.152 